\title{
REVIEW OF METHODS FOR SIZE AND MORPHOLOGY DETERMINATION OF VESICLES IN NIOSOME DISPERSION
}

\section{E.I. Diskaeva ${ }^{a}$, O.V. Vecher ${ }^{a}$, E.N. Diskaevab ${ }^{b}$ I.A. Bazikov ${ }^{a}$, K.S. Elbekyan ${ }^{a}$}

a Stavropol State Medical University, Stavropol, 355017, Russian Federation

b Branch of the Federal State Budget Educational Institution of Higher Education "MIREA - Russian Technological University" in Stavropol, Stavropol, 355035, Russian Federation

Corresponding author: e_diskaeva@mail.ru

Article info

Received 20.04.20, accepted 27.05.20

Article in English

For citation: Diskaeva E.I., Vecher O.V., Diskaeva E.N., Bazikov I.A., Elbekyan K.S. Review of methods for size and morphology determination of vesicles in niosome dispersion. Scientific and Technical Journal of Information Technologies, Mechanics and Optics, 2020, vol. 20, no. 3, pp. 377-381 (in English). doi: 10.17586/2226-1494-2020-20-3-377-381

\section{Abstract}

The paper provides comparative analysis of direct and indirect methods for assessing the size and morphological characteristics of niosome dispersions. Niosome sizes vary over a wide range: from $20 \mathrm{~nm}$ to $10 \mu \mathrm{m}$ and more. The vesicle shape can also vary from perfectly spherical to elliptical and complexly curved in the case of aggregation. The size and shape of large particles with a diameter greater than $1 \mu \mathrm{m}$ can be assessed by light microscopy. To study smaller vesicles, about $0.1-0.5 \mu \mathrm{m}$, it is advisable to use the technique of dynamic light scattering. Photometric method is reasonable to be used for an indirect assessment of the size of niosome vesicles in the range of 40-130 nm. For surface morphology study of the smallest niosomes, the method of scanning electron microscopy seems to be optimal.

Keywords

niosome dispersions, niosome vesicle size, dynamic light scattering, scanning electron microscopy, photometric method

\section{ОБЗОР МЕТОДОВ ОПРЕДЕЛЕНИЯ РАЗМЕРОВ И МОРФОЛОГИИ ВЕЗИКУЛ НИОСОМАЛЬНОЙ ДИСПЕРСИИ}

\section{Е.И. Дискаева ${ }^{a}$, О.В. Вечер ${ }^{a}$, Е.Н. Дискаева ${ }^{b}$, И.А. Базиков ${ }^{a}$, К.С. Эльбекьян ${ }^{a}$}

a Ставропольский государственный медицинский университет, Ставрополь, 355017, Российская Федерация

b Филиал федерального государственного бюджетного образовательного учреждения высшего образования «МИРЭА -

Российский технологический университет» в г. Ставрополе, Ставрополь, 355035, Российская Федерация

Адрес для переписки: e diskaeva@mail.ru

Информация о статье

Поступила в редакцию 20.04.20, принята к печати 27.05.20

Язык статьи - английский

Ссылка для цитирования: Дискаева Е.И., Вечер О.В., Дискаева Е.Н., Базиков И.А., Эльбекьян К.С. Обзор методов определения размеров и морфологии везикул ниосомальной дисперсии // Научно-технический вестник информационных технологий, механики и оптики. 2020. Т. 20. № 3. С. 377-381. doi: 10.17586/2226-1494-2020-20-3-377-381

\section{Аннотация}

Выполнен сравнительный анализ прямых и косвенных методов оценки размеров и морфологических характеристик ниосомальных дисперсий. Размеры ниосом варьируются в широких пределах: от 20 нм до 10 мкм и более. Форма везикул также может изменяться - от идеально сферической до эллиптической, и сложно изогнутой в случае агрегации. Размеры и форму крупных ниосом, диаметром более 1 мкм, можно оценить с помощью световой микроскопии. Для исследования более мелких везикул, размером около 0,1-0,5 мкм, целесообразно использовать метод динамического рассеяния света. Для косвенной оценки размера ниосомальных везикул в диапазоне 40-130 нм целесообразно использовать фотометрический метод. При исследовании морфологии поверхности мельчайших ниосом оптимальным представляется метод сканирующей электронной микроскопии.

\section{Ключевые слова}

ниосомальная дисперсия, размер ниосомальных везикул, динамическое рассеяние света, сканирующая электронная микроскопия, фотометрический метод 


\section{Introduction}

Recently, creation of innovative dosage forms of existing drugs has been developing intensively in parallel with the development of new drugs. The objective is to increase the bioavailability of drugs that have already proven their effectiveness together with the decrease in the administered dose and the risk of possible side-effects [1-4]. One of these promising "delivery systems" of drugs is the aqueous niosome dispersion. Niosomes are stable, single-layer or multi-layer vesicles of non-ionic surfactants. Non-ionic surfactants have advantages over ionic ones, since they are usually biocompatible and minimally bind to proteins [5]. Various components can be integrated into the bilayer lipid membranes by means of niosomes, affecting their stability, electrophoretic mobility and controllability by external electromagnetic fields. Besides, the problem of the prolonged drug action can be solved by the size control of the niosomes and the time of the substance release from them [6-8].

Currently, there are no experimental and theoretical approaches for a comprehensive description of the niosome vesicle properties that affect their ability to transport drugs into the aqueous environment. The possibility of obtaining morphologically homogeneous dispersed compounds with desired sizes provides to move forward in the direction of drug development.

\section{Material and Methods}

We used a water solution of niosomes consisted of a shell in the form of a water-insoluble double layer of a nonionic surfactant, which is a group of dimethiconcopolyol substances. They are esters of polyethylene glycol and polydimethylsiloxane (PDMS) backbone [9-11]. To obtain the capsules of silicone nature, physicochemical methods for the synthesis of molecules were applied. The shell of the obtained niosome vesicles were generated from PEG-12 Dimethicone [12]. Samples were diluted with ultrapure water (with concentration $C=0.01 \%$ )

The vesicle formation process is the self-organization of molecules and their simultaneous assembly into associates. Wherein, solution phase separation happens, and the resulting vesicles have significant anisotropy of physical properties in the radial direction. Significant influence on the size and shape of niosomes is exerted by their concentration in an aqueous solution. The growth in the content of the vesicles per volume unit inevitably leads to their fusion and violation of the form symmetry.

\section{Results and Discussion}

Optical microscopy. Light microscopy can be used for estimation of size and morphology of niosomes with micron and submicron diameter.

Microscopy of the sample of the above described niosome dispersion was performed by Micromed 2-20 microscope with magnification factor equal to 400 and LOMO digital camera.

The microphotograph on Fig. 1 shows that the sample is a fraction containing a number of conglomerates formed

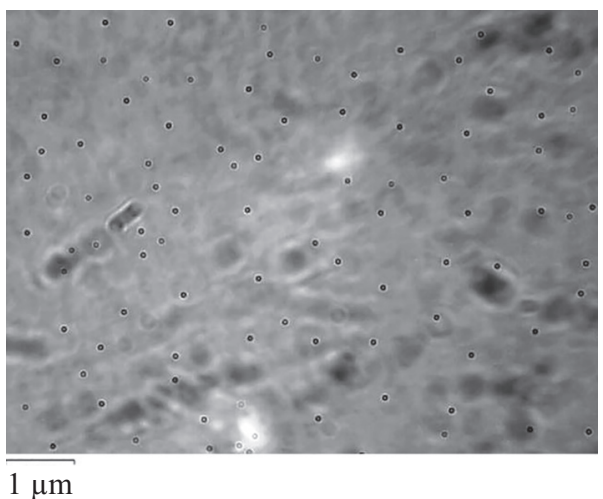

Fig. 1. Microphotography of niosome dispersion

by the merger of the individual niosomes. In general, the sample looks fairly homogeneous, since most of them have dimensions smaller than the resolution limit of an optical microscope.

Thus, the microphotograph obtained by optical microscopy can assess the homogeneity of the niosome solution only in the first approximation revealing the presence of large aggregates in the finely dispersed system.

Dynamic light scattering (DLS). Particle size can be determined by measuring the random changes in the intensity of light scattered from a niosome solution. The limitations imposed by this method on the dimensions of the particles being measured give the possibility to be used for the research of niosome solutions with the effective diameters from a few nanometers to several microns.

The linear dimensions of the niosome dispersion particles were measured using the PHOTOCORCOMPLEX multifunctional spectrometer for dynamic and static light scattering (He-Ne laser, $633 \mathrm{~nm}$ ). Vesicle sizes were calculated applying FAST Version 2.8.3 software. (Alango Ltd.) According to the Einstein-Stokes formula, which relates the particle size to their diffusion coefficient and fluid viscosity:

$$
R=\frac{k T}{6 \pi \eta D},
$$

where $k$ - Boltzmann constant; $T$ - absolute temperature; $\eta$ - shear viscosity of the medium; $D$ - diffusion coefficient.

Analysis of the obtained results (Fig. 2) provides for the conclusion that the size of the niosomes in the sample varies considerably. The size distribution is polymodal with

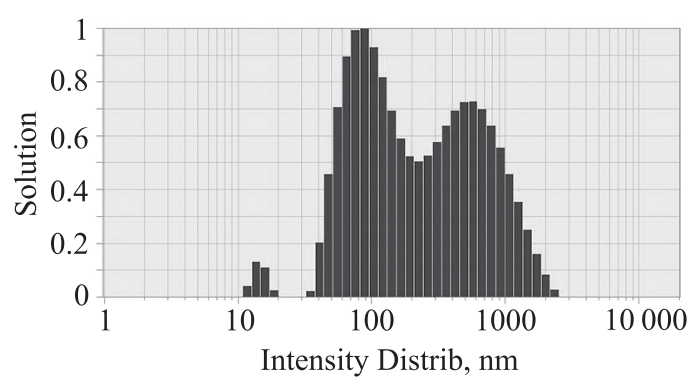

Fig. 2. The results of light scattering on niosomes obtained by PHOTOCORCOMPLEX multifunctional spectrometer 
three peaks corresponding to $15 \mathrm{~nm}, 100 \mathrm{~nm}$ and $657 \mathrm{~nm}$, respectively. The latter result, apparently, is associated with the scattering not on individual vesicles, but on their conglomerates.

The method gives a large error related to non-ideal spherical form of the particles and the presence of a certain number of randomly arranged aggregates in the sample, as it was shown in case of optical microscopy application.

Now, the method of dynamic light scattering is one of the most popular methods for estimating the size of nanoparticles, since it provides the possibility to obtain data and carry out their mathematical processing automatically with relatively low material costs and short duration of the experiment $[13,14]$.

Scanning electron microscopy. The size of nanoparticles can be defined using scanning electron microscopic method (Scanning Electron Microscopy (SEM) Tescan Mira $3 \mathrm{Im}$ ). The particle size determined by Image J, Excel statistical package program was used to perform the analysis.

Fig. 3 shows that water solution of niosomes consists of particles with various diameter sand niosomes, that are spherical particles in their majority.

This fact implies that for equivalent diameter determination of the particles the projected diameter can be used. The area of the projected diameter will be equal to the area of the particle projection image [15].

The cumulative distribution function (distribution density) was used to evaluate the average particle size.

Particle probability density function of the size of niosomes is shown in Fig. 4.

Research results present two most probable values for sizes of $100 \mathrm{~nm}$ and $160 \mathrm{~nm}$, which do not contradict the data obtained by the method of dynamic light scattering.

This method makes it possible to determine accurately the niosome sizes in the sample, as well as to carry out morphological and dispersion analysis. In addition, the possibility of visual control excludes large conglomerates of vesicles from the study.

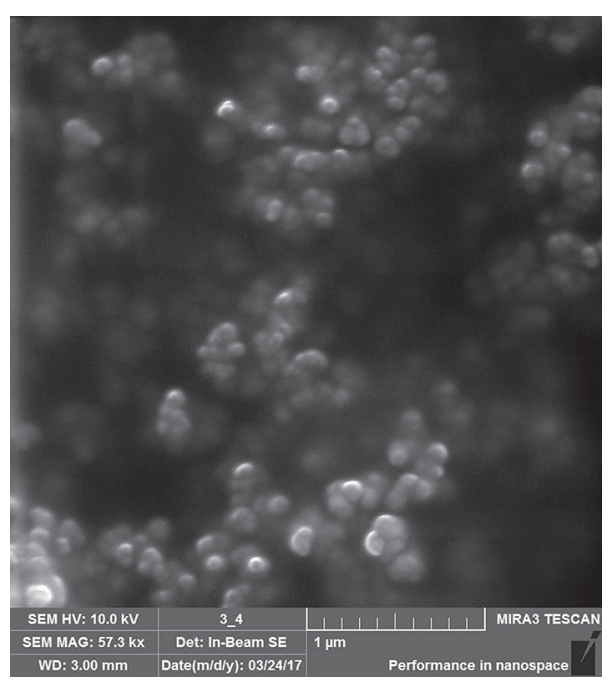

Fig. 3. Micrograph of niosomes obtained by Scanning Electron Microscopy

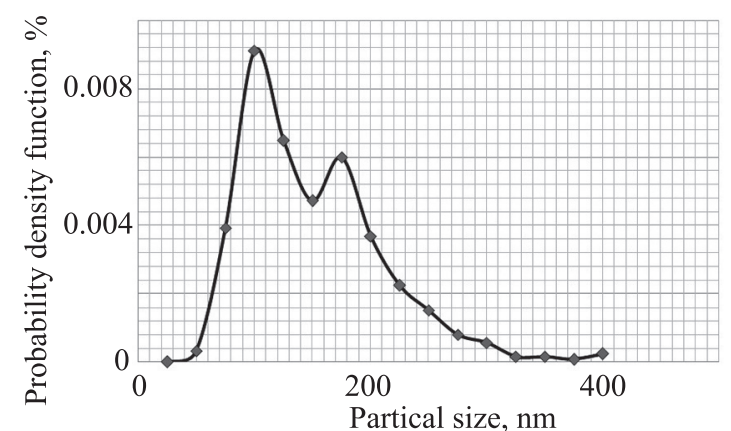

Fig. 4. Probability density function of particle size distribution

However, this method has some limitations, since it is impossible to study sufficiently large amount of material, as well as the complexity of the measurement process itself. In addition, the lack of automation in the selection of measured particles gives a subjective contribution to the results of the study.

Photometric method. With monochromatic radiation passages and a wavelength from 400 to $750 \mathrm{~nm}$, through a solution of niosomes with the dimensions much smaller than these quantities, the light rays are not reflected from them, but scattered.

In this case, the Geller formula is applicable related to the optical density of the solution of the incident light wavelength. The formula contains a coefficient and its value depends on the average particle size:

$$
D=K \lambda^{-\chi},
$$

where $D$ - optical density; $K$ - coefficient independent of the light wavelength; $\lambda-$ light wavelength; $\chi-$ coefficient, the value of which varies from 1 to 4 depending on the size of the scattering particles.

The Geller calibration curve is shown in Fig. 5. It can be used to determine graphically the radius of particles.

For particles with a radius from 40 to $130 \mathrm{~nm}$, the calibration dependence is linear. Therefore, we can establish the analytical dependence $r=f(\chi)$. In the specified range it has the form:

$$
r=\frac{4.875-\chi}{0.031} .
$$

This expression is true for $\chi=0.9750-3.6750$.

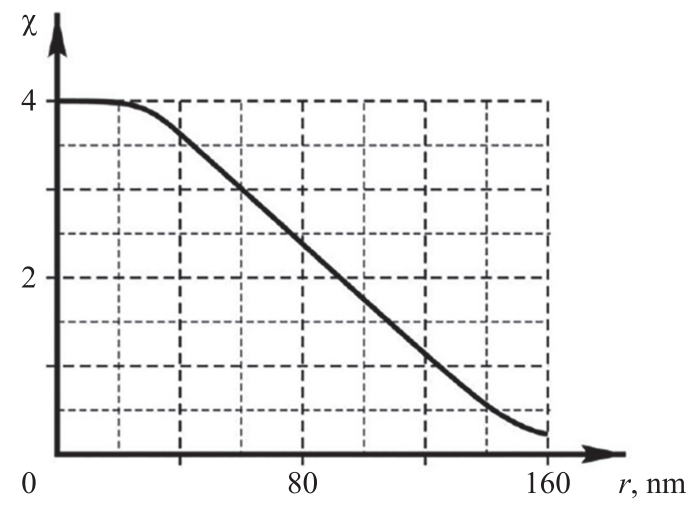

Fig. 5. Geller curve 
The algorithm for the size determination of niosome vesicles by photometric method is described in details [16]. According to the experiment results, the effective diameter of the niosomes was equal to $108 \pm 12 \mathrm{~nm}$.

Photometric method does not provide information on the dispersion composition of the niosome solution, however, due to its implementation simplicity and the absence of the complex equipment requirements, it seems to be a good alternative to SEM Tescan Mira $3 \mathrm{Im}$ or Photocor Complex application for the express estimation of the vesicle sizes by coagulation.

\section{Conclusion}

Niosome creation with controlled size parameters, shape and morphology is one of the promising tasks of modern science. The methods for producing of single-layer and multilayer vesicles with sizes from $20 \mathrm{~nm}$ to $10 \mu \mathrm{m}$ and more are described.

Range of sizes and morphological properties of niosomes can be set by the conditions of production and various components. Thus, the application of a certain

\section{References}

1. Abdelkader H., Farghaly U., Moharram H. Effects of surfactant type and cholesterol level on niosomes physical properties and in vivo ocular performance using timolol maleate as a model drug. Journal of Pharmaceutical Investigation, 2014, vol. 44, no. 5, pp. 329-337. doi: 10.1007/s40005-014-0121-8

2. Sanklecha V.M., Pande V.V., Pawar S.S., Pagar O.B., Jadhav A.C. Review on niosomes. Austin Pharmacology \& Pharmaceutics, 2018, vol. 3, no. 2, pp 1016 .

3. Md. Rageeb Md. Usman, Prasanna R. Ghuge, Bharat V. Jain. Niosomes: a novel trend of drug delivery. European Journal of Biomedical and Pharmaceutical Sciences, 2017, vol. 4, no. 7, pp. 436-442.

4. Bartelds R., Nematollahi M.H., Pols T., Stuart M.C.A., Pardakhty A., Asadikaram G., Poolman B. Niosomes, an alternative for liposomal delivery. PLoS ONE, 2018, vol. 13, no. 4, pp. e0194179. doi: 10.1371/journal.pone.0194179

5. Bayindir Z.S., Yuksel N. Characterization of niosomes prepared with various nonionic surfactants for paclitaxel oral delivery. Journal of Pharmaceutical Sciences, 2010, vol. 99, no. 4, pp. 2049-2060. doi: 10.1002/jps.21944

6. Yeo P.L., Lim C.L, Chye S.M., Ling A.P.K., Koh R.Y. Niosomes: a review of their structure, properties, methods of preparation, and medical applications. Asian Biomedicine, 2017, vol. 11, no. 4, pp. 301-313. doi: 10.1515/abm-2018-0002

7. Kamal M., Maher M., Ibrahim A., Louisan D. An overview on niosomes: a drug nanocarrier. Drug Designing \& Intellectual Properties International Journal, 2018, vol. 1, no. 5. doi: 10.32474/DDIPIJ.2018.01.000125

8. Agarwal S., Bakshi V., Vitta P., Raghuram A.P., Pandey S., Udupa N Effect of cholesterol content and surfactant HLB on vesicle properties of niosomes. Indian Journal of Pharmaceutical Sciences, 2004, vol. 66, no. 1, pp. 121-123.

9. Bazikov I.A., Beyer E.V., Maltsev A.N., Goptareva E.A., Malinina N.I., Selimov M.A., Botasheva V.S. Study cardiotoxicity niosomal forms of doxorubicin. Medical News of North Caucasus, 2016, vol. 11, no. 3, pp. 421-425. (in Russian). doi: 10.14300/mnnc.2016.11093

10. Bazikov I.A., Lukinova V.V., Maltsev A.N., Diskaeva E.I., Aytekova S.R. Interaction niosomal doxorubicin cell membranes. Medical News of North Caucasus, 2016, vol. 11, no. 1, pp. 108-111. (in Russian). doi: 10.14300/mnnc.2016.11011

11. Bazikov I.A., Lukinova V.V., Malinina N.I., Maltsev A.N. Study of the mechanisms of intercellular interaction of the niosomal form of the antitumor drug doxorubicin with plasma membranes. Eurasian Union of Scientists, 2016, no. 3(24), pp. 34-35. (in Russian) preparation technology determines the expected particle sizes.

Methods for estimation of the niosomes sizes are based on the interaction of particles with light waves, or by the flow of electrons in case of scanning electron microscopy. Therefore, when choosing a method, we are guided by the ratio of the light wavelength and the expected diameter of the vesicles.

In the study of large particles with a diameter in excess of $1 \mu \mathrm{m}$, light microscopy is used in combination with various methods of increasing resolution. To estimate the particle sizes in the order of $0.1-0.5 \mu \mathrm{m}$, it is advisable to apply the technique of dynamic light scattering and photometric method is reasonable for niosomes with the diameter in the range of $40-130 \mathrm{~nm}$. The method of scanning electron microscopy seems to be optimal in the surface morphology study of the smallest niosomes.

To obtain detailed information about the shape of niosomes and their size distribution, methods directly evaluating images should be applied. For preliminary assessment the method of dynamic light scattering or photometric method can be used.

1. Abdelkader H., Farghaly U., Moharram H. Effects of surfactant type and cholesterol level on niosomes physical properties and in vivo ocular performance using timolol maleate as a model drug // Journal of Pharmaceutical Investigation. 2014. V. 44. N 5. P. 329-337. doi: 10.1007/s40005-014-0121-8

2. Sanklecha V.M., Pande V.V., Pawar S.S., Pagar O.B., Jadhav A.C. Review on niosomes // Austin Pharmacology \& Pharmaceutics. 2018. V. 3. N 2. P. 1016.

3. Md. Rageeb Md. Usman, Prasanna R. Ghuge, Bharat V. Jain. Niosomes: a novel trend of drug delivery // European Journal of Biomedical and Pharmaceutical Sciences. 2017. V. 4. N 7. P. 436-442.

4. Bartelds R., Nematollahi M.H., Pols T., Stuart M.C.A., Pardakhty A., Asadikaram G., Poolman B. Niosomes, an alternative for liposomal delivery // PLoS ONE. 2018. V. 13. N 4. P. e0194179. doi: 10.1371/journal.pone.0194179

5. Bayindir Z.S., Yuksel N. Characterization of niosomes prepared with various nonionic surfactants for paclitaxel oral delivery // Journal of Pharmaceutical Sciences. 2010. V. 99. N 4. P. 2049-2060. doi: 10.1002/jps.21944

6. Yeo P.L., Lim C.L, Chye S.M., Ling A.P.K., Koh R.Y. Niosomes: a review of their structure, properties, methods of preparation, and medical applications // Asian Biomedicine. 2017. V. 11. N 4. P. 301313. doi: 10.1515/abm-2018-0002

7. Kamal M., Maher M., Ibrahim A., Louisan D. An overview on niosomes: a drug nanocarrier // Drug Designing \& Intellectual Properties International Journal. 2018. V. 1. N 5. doi: 10.32474/DDIPIJ.2018.01.000125

8. Agarwal S., Bakshi V., Vitta P., Raghuram A.P., Pandey S., Udupa N. Effect of cholesterol content and surfactant HLB on vesicle properties of niosomes // Indian Journal of Pharmaceutical Sciences. 2004. V. 66. N 1. P. 121-123.

9. Базиков И.А., Бейер Э.В., Мальцев А.Н., Селимов М.А., Малинина Н.И., Лукинова В.В., Боташева В.С. Исследование кардиотоксичности ниосомальной формы доксорубицина // Медицинский вестник Северного Кавказа. 2016. Т. 11. № 3. С. 421-425. doi: 10.14300/mnnc.2016.11093

10. Базиков И.А., Лукинова В.В., Мальцев А.Н., Дискаева Е.И., Айтекова С.Р Взаимодействие ниосомального доксорубицина с мембранами клеток // Медицинский вестник Северного Кавказа. 2016. Т. 11. № 1. С. 108-111. doi: 10.14300/mnnc.2016.11011

11. Базиков И.А., Лукинова В.В., Малинина Н.И., Мальцев А.Н. Изучение механизмов межклеточного взаимодействия ниосомальной формы противоопухолевого препарата доксорубицина 
12. Bazikov I.A., Omel'janchuk P.A. System for delivery of bioactive substances by using niosomes. Patent RU2320323, 2008. (in Russian)

13. Levin A.D., Shmytkova E.A., Khlebtsov B.N. Multipolarization dynamic light scattering of nonspherical nanoparticles in solution. Journal of Physical Chemistry C, 2017, vol. 121, no. 5, pp. 3070 3077. doi: 10.1021 acs.jpcc.6b10226

14. Sakurai T., Trirongjitmoach S., Nishibata Y., Namita T., Tsuji M., Hui S.-P., Jin S., Shimizu K., Chiba H. Measurement of lipoprotein particle sizes using dynamic light scattering. Annals of Clinical Biochemistry, 2010, vol. 47, no. 5, pp. 476-481. doi: 10.1258/acb.2010.010100

15. Diskaeva E.I., Vecher O.V., Bazikov I.A., Vakalov D.S. Particle size analysis of niosomes as a function of temperature. Nanosystems: physics, chemistry, mathematics, 2018, vol. 9, no. 2, pp. 290-294. doi: 10.17586/2220-8054-2018-9-2-290-294

16. Diskaeva E.I., Bazikov I.A., Vecher O.V., Timchenko V.P., Selimov M.A. Evaluation of applicability of photometric method for determining the size of vesicules of niosomal dispersion. Medical News of North Caucasus, 2018, vol. 13, no. 1, pp. 108-110. (in Russian). doi: 10.14300/mnnc.2018.13030

\section{Authors}

Elena I. Diskaeva - PhD, Associate Professor, Head of Chair, Stavropo State Medical University, Stavropol, 355017, Russian Federation, Scopus ID: 57189445202, ORCID ID: 0000-0002-6095-7010, e_diskaeva@mail.ru

Olga V. Vecher - PhD, Associate Professor, Associate Professor, Stavropol State Medical University, Stavropol, 355017, Russian Federation, Scopus ID: 57201682661, ORCID ID: 0000-0002-6743-874X, vecher.olga@mail.ru

Elena N. Diskaeva - PhD, Associate Professor, Branch of the Federal State Budget Educational Institution of Higher Education "MIREA - Russian Technological University" in Stavropol, Stavropol, 355035, Russian Federation, ORCID ID: 0000-0002-5185-6023, diskaevapes@mail.ru

Igor A. Bazikov - D.Sc., Professor, Head of Chair, Stavropol State Medical University, Stavropol, 355017, Russian Federation, Scopus ID: 56500539100, ORCID ID: 0000-0001-9207-6552, bazikov@list.ru

Karine S. Elbekyan - D.Sc., Associate Professor, Head of Chair, Stavropol State Medical University, Stavropol, 355017, Russian Federation, Scopus ID: 6507554431, ORCID ID: 0000-0003-2403-8663, karinasgma@inbox.ru с плазматическими мембранами // Евразийский Союз Ученых. 2016. № 3-2(24). С. 34-35.

12. Базиков И.А., Омельянчук П.А. Система доставки биологически активных веществ с помощью ниосом. Патент RU2320323. Бюл. 2008. № 9.

13. Levin A.D., Shmytkova E.A., Khlebtsov B.N. Multipolarization dynamic light scattering of nonspherical nanoparticles in solution // Journal of Physical Chemistry C. 2017. V. 121. N 5. P. 3070-3077. doi: 10.1021/acs.jpcc.6b10226

14. Sakurai T., Trirongjitmoach S., Nishibata Y., Namita T., Tsuji M., Hui S.-P., Jin S., Shimizu K., Chiba H. Measurement of lipoprotein particle sizes using dynamic light scattering // Annals of Clinical Biochemistry. 2010. V. 47. N. 5. P. 476-481. doi: 10.1258/acb.2010.010100

15. Diskaeva E.I., Vecher O.V., Bazikov I.A., Vakalov D.S. Particle size analysis of niosomes as a function of temperature // Наносистемы: физика, химия, математика. 2018. Т. 9. № 2. С. 290-294. doi: 10.17586/2220-8054-2018-9-2-290-294

16. Дискаева Е.И., Базиков И.А., Вечер О.В. Тимченко В.П., Селимов М.А. Оценка применимости фотометрического метода для определения размера везикул ниосомальной дисперсии // Медицинский вестник Северного Кавказа. 2018. Т. 13. № 1. C. 108-110. doi: 10.14300/mnnc.2018.13030

\begin{abstract}
Авторы
Дискаева Елена Игоревна - кандидат физико-математических наук, доцент, заведующая кафедрой, Ставропольский государственный медицинский университет, Ставрополь, 355017, Российская Федерация, Scopus ID: 57189445202, ORCID ID: 0000-0002-6095-7010, e_diskaeva@mail.ru

Вечер Ольга Владимировна - кандидат физико-математических наук, доцент, доцент, Ставропольский государственный медицинский университет, Ставрополь, 355017, Российская Федерация, Scopus ID: 57201682661, ORCID ID: 0000-0002-6743-874X, vecher.olga@mail.ru Дискаева Елена Николаевна - кандидат физико-математических наук, доцент, Филиал федерального государственного бюджетного образовательного учреждения высшего образования «МИРЭА - Российский технологический университет» в г. Ставрополе, Ставрополь, 355035, Российская Федерация, ORCID ID: 0000-0002-5185-6023, diskaevapes@mail.ru

Базиков Игорь Александрович - доктор медицинских наук, профессор, заведующий кафедрой, Ставропольский государственный медицинский университет, Ставрополь, 355017, Российская Федерация, Scopus ID: 56500539100, ORCID ID: 0000-0001-9207-6552, bazikov@list.ru

Эльбекьян Карине Сергеевна - доктор биологических наук, доцент, заведующая кафедрой, Ставропольский государственный медицинский университет, Ставрополь, 355017, Российская Федерация, Scopus ID: 6507554431, ORCID ID: 0000-0003-2403-8663, karinasgma@inbox.ru
\end{abstract}

